\title{
COULD A "YELLOW CARD" FOR NATIONAL PARLIAMENTS STRENGTHEN JUDICIAL AS WELL AS POLITICAL POLICING OF SUBSIDIARITY?
}

\begin{abstract}
Derrick Wyatt*
Summary: It is argued that subsidiarity should be interpreted, in accordance with the principle of effectiveness, as requiring that the Community should only act where the objectives of the proposed action can only be achieved at Community level. Subsidiarity has not so far been an effective brake on action by the European institutions, and the Court's scrutiny of Community acts for compliance with subsidiarity has been undemanding. The Constitution Treaty seeks to confirm and strengthen application of subsidiarity. Monitoring by national parliaments, and in particular the possibility for one third to object to a proposal on subsidiarity grounds, thus "showing a yellow card," could lead to improved compliance with subsidiarity by the lawmaking institutions; and the "yellow card" procedure could change the dynamics of judicial enforcement of subsidiarity. Where national parliaments "raised a yellow card," but the Commission maintained its draft, one possibility (which the present writer would advocate) would be that in any subsequent judicial proceedings the Court of Justice would require the Commission to demonstrate that the national parliaments had made a manifest error of appraisal in objecting to the draft act on subsidiarity grounds. Giving teeth to subsidiarity by entrusting national parliaments with responsibility for monitoring its application, and reinforcing that responsibility with an appropriate judicial response from the Court of Justice, could enhance the sense of "ownership" of the European project at national level. Although it appears unlikely that the Constitution Treaty will come into force, that fact need not prevent the introduction by other means of subsidiarity monitoring by national parliaments, and the adoption by the Court of Justice of the approach indicated.
\end{abstract}

\section{Introduction}

The aim of this article is to recall and develop the critical analysis of subsidiarity which the present writer has advanced in recent years. ${ }^{1}$ The

\footnotetext{
* Professor Derrick Wyatt QC, St Edmund Hall, Oxford.

${ }^{1}$ See most recently: D Wyatt, A Dashwood and others, Wyatt and Dashwood's European Union Law (5th edn Thomson/Sweet and Maxwell, London 2006) 103-110.
} 
new argument to be advanced here is that a system of political monitoring of subsidiarity by national parliaments would provide the justification for a new approach to the judicial control of subsidiarity. The present writer will indicate what such a new approach might be, and argue that, if monitoring by national parliaments is introduced, such an approach should be adopted by the Court of Justice.

\section{Origins of Subsidiarity ${ }^{2}$}

The principle of subsidiarity, though not under that name, was first introduced as a principle of the Community legal order by the Single European Act, which introduced an Environmental Title into the (then) EEC Treaty, and provided that the Community should take action to the extent to which environmental objectives "can be attained better at Community level than at the level of the individual Member States."3

Subsidiarity in its present form was introduced by the Maastricht amendments to the EEC Treaty. ${ }^{4}$ Subsidiarity was a response to the wide and expanding scope of Community lawmaking competence and to the increasing exercise of that competence. The wide and expanding scope of Community lawmaking competence resulted from several factors: (a) the original EEC Treaty gave fairly wide lawmaking competence to the Council; (b) lawmaking competences under that Treaty were interpreted widely by the European institutions, including the Court of Justice, and by the Member States in their capacity as members of the Council; (c) additions to lawmaking competences had been made, ${ }^{5}$ and were being made. ${ }^{6}$ While these latter factors contributed to the growth of Community competence, the adoption in practice of qualified majority voting subsequent to the amendments introduced by the SEA contributed to an increase in the exercise of that competence post 1987. On one measure, the annual number of binding acts adopted by the Community institutions more

\footnotetext{
2 There is an extensive literature on the principle of subsidiarity, much of it now overtaken by events. For a selection of views, see V Constantinesco, 'Who's afraid of Subsidiarity?' (1991) 11 YEL 33; N Emiliou, 'Subsidiarity - An Effective Barrier against the Enterprises of Ambition?' (1992) 17 ELRev 383; AG Toth, 'The Principle of Subsidiarity in the Maastricht Treaty' (1992) 29 CMLRev 1079; D Cass, 'The Word that Saves Maastricht? The Principle of Subsidiarity and the Division of Powers within the European Community' (1992) 29 CMLRev 1107; E Mattina, 'Subsidiarite, Democratie et Transparence' (1992) 4 RMUE 203; JP Gonzalez, 'The Principle of Subsidiarity' (1995) 20 ELRev 355; D Wyatt, 'Subsidiarity - Is it too Vague to be Effective as a Legal Principle?' in K Nicolaidis and S Weatherill (eds), Whose Europe? National Models and the Constitution of the European Union (OUP/European Studies, Oxford 1993) <http://www.europeanstudies.ox.ac.uk> accessed 9 August 2006

${ }^{3}$ EEC Treaty (Treaty of Rome) art 130R (4)

${ }^{4}$ EC Treaty (Treaty of Rome, as amended) art 3b

5 The Single European Act 1986

6 Treaty on European Union (Maastricht Treaty)
} 
than doubled between 1986 and 1992, from 311 to $752 .{ }^{7}$ In the run up to the agreement on the Maastricht amendments, some Member States, including Spain, France and Italy, had sought a reference to subsidiarity in the preamble of the EC Treaty. ${ }^{8}$ The main advocates of subsdiarity as a legally binding principle inhibiting the exercise of Community competence had been Germany and the United Kingdom. ${ }^{9}$

\section{How effective has subsidiarity been in practice?}

Views differ as to the effectiveness of subsidiarity as a brake on Community action in the hands of the political institutions and the Court of Justice. The Constitution Treaty in a Protocol on Subsidiarity and Proportionality seeks to confirm and strengthen application of susidiarity, and provides for monitoring of the application of the principle by national parliaments and by the Court of Justice. The European Unioin Committee of the Upper House of the United Kingdom Parliament (the House of Lords) has examined the proposed monitoring procedures in some detail. The European Union Committee of the House of Lords undertook in the Session 2004-2005 an assessment of subsidiarity monitoring in order "to focus Parliamentary and public attention on subsidiarity monitoring" and to advise the House of Lords on how, if the Constitution Treaty comes into force, the House might fulfil its new obligations. ${ }^{10} \mathrm{~A}$ written question posed by the Committee to the British Government gives some indication of the balance of the evidence received by the Committee: "Looking at the written evidence we have received it seems that most people believe that thus far the principle of subsidiarity has not acted as an effective "brake" on the exercise of lawmaking powers at the Community level. Do you agree and if so why is this?" The reply by the Minister for Europe gave a firm endorsement of subsidiarity in practice:

“The Government believes that... the EU's general direction has been positively influenced by the institutions' increasing application of subsidiarity. In particular the Government believes that the princi-

\footnotetext{
7 Antonio Estella, The EU Principle of Subsidiarity and its Critique (OUP, Oxford 2002) 20, Table I.3.

8 Javier Elorza, 'Subsidiariedad' in Breve diccionario del Tratado de la Unión Europea (Vol VI Política exterior, 29 Otoño 1992), 126. See also Estella (n 7) 85.

${ }^{9}$ Estella (n7) 85. Also Cloos, Reinesch and others, Le Traité de Maastricht: Genèse, Analyse, Commentaires (Bruylant, Bruxelles 1993) 149. And see Schilling, 'A New Dimension of Subsidiarity: Subsidiarity as a Rule and a Principle' (1994) 14 YEL 203, referring to Case, 'The Word that Saved Maastricht? The Principle of Subsidiarity and the Division of Powers within the European Community' (1992) 29 CMLR 1107.

${ }^{10}$ Report with Evidence from the EU Committee, 'Strengthening national parliamentary scrutiny of the EU - the Constitution's subsidiarity early warning mechanism', HL (2004-2005) 14 <http://www.publications.parliament.uk/pa/ld200405/ldselect/ldeucom/101/10102.htm> accessed 9 August 2006.
} 
ple of subsidiarity has worked as an effective tool in influencing the formulation of European legislation." ${ }^{11}$

The Government's position was consistent with evidence offered by certain British MEPs, ${ }^{12}$ who noted that every proposal emerging from Brussels already had to contain recitals indicating why and how the proposal complied with the principle of subsidiarity. The Committee contrasted with the Government's view that "the institutions are applying the principle in practice as part of the policy-making and legislative process," an alternative view, to the effect "that subsidiarity has so far received only token attention from the EU institutions and has certainly not served as a founding principle to encourage self-restraint on the part of the Community institutions in their law making activities." 13 The Committee cited in support of this proposition evidence submitted by Professors Weatherill and Wyatt of the University of Oxford. Professor Weatherill had argued to the Committee that "so far subsidiarity has done little to shake existing cultures of lawmaking at EU level." ${ }^{14}$ The evidence of the present writer to the Committee is cited as follows:

"Professor Wyatt has offered three possible reasons to explain why subsidiarity might thus far have failed to live up to its promise:

- Subsidiarity is "a principle ill-designed to achieve the objective of ensuring that decisions are taken as closely as possible to the citizen”...

- There is political indifference towards the principle or "antipathy on the part of the Community institutions and some Member States"..

- There is "constitutional indifference or antipathy on the part of the Court of Justice"...

The Committee noted this division of opinion about the efficacy of subsidiarity in practice, and expressed the hope that the new Protocol to the Constitution Treaty would "provide a vehicle for highlighting and invigorating subsidiarity compliance across the Union." ${ }^{16}$ In its summary of recommendations, the Committee expressed the hope "that the Court will take a more critical approach to subsidiarity, particularly in ensuring that the justification for action at Union level is adequate."17 The present writer would argue that there is certainly room for a more critical approach to subsidiarity on the part of the Court of Justice, and for a more

\footnotetext{
${ }^{11}$ Report (n10), Minutes of Evidence para 66.

12 MEPs Richard Corbett and Andrew Duff.

${ }^{13}$ Report (n10) para 77.

14 Ibid.

15 Report (n10) [78].

${ }^{16}$ Report (n10) [84].

17 Ibid para 244.
} 
rigorous approach to application of the principle to proposals for legislation on the part of the Commission, Council and Parliament.

\section{Subsidiarity should be interpreted and applied in a way which is effective in practice}

\section{Subsidiarity aims to identify objectives which can only be achieved by Community wide action - the two fold test is in truth a single test}

Subsidiarity is first and foremost a political principle, to be interpreted and applied by the Community institutions. Yet it is equally a fundamental principle of the Community legal order, to be interpreted in light of its text, its aim, and the principle of effectiveness.

Article 5 of the EC Treaty provides that, "in areas which do not fall within its exclusive competence, the Community shall take action, in accordance with the principle of subsidiarity, only if and insofar as the objectives of the proposed action cannot be sufficiently achieved by the Member States and can therefore, by reason of the scale or effects of the proposed action, be better achieved by the Community."

The text thus appears to lay down a "dual" test or requirement for Community action, (a) that the objectives of the proposed action cannot be sufficiently achieved by the Member States, and (b) that those objectives can by reason of the scale or effects of the proposed action, be better achieved by the Community. It will be argued that this test should be read as posing a single question: can the objectives of the proposed action only be achieved by Community wide action? If the answer to this question is "yes", the proposed action is consistent with the principle of subsidiarity; if the answer is "no", then the objectives can be sufficiently achieved at national level and the principle of subsidiarity is not satisfied.

It is textually possible to interpret the dual test for subsidiarity in a way which minimises or eliminates its potential to inhibit Community action. Thus a proposal for Community wide rules on any subject matter at all within Community competence might be said to pass the dual test, on the grounds that Member States cannot individually achieve the objectives of the proposal (the adoption of Community wide rules), while the scale or effects of the proposed action (Community wide rules) can be better (indeed only) achieved at Community level. Commission references to subsidiarity in explanatory memoranda to some measures seem to imply such an approach. ${ }^{18}$ Support for this approach might be derived

\footnotetext{
${ }^{18}$ See e.g., the Communication from the Commission to the Council, the European Parliament, the Economic and Social Committee and the Committee of the Regions, on certain Community measures to combat discrimination (1999/C 369/03) - paragraph on subsid-
} 
from terms in which the Court rejected the argument that the adoption of Council Directive 93/104/EC concerning certain aspects of the organization of working time contravened the principle of subsidiarity. The Court stated that once the Council had found that it was necessary to improve the existing level of protection as regards the health and safety of workers and to harmonize conditions in this area, achievement of that objective through the imposition of minimum requirements necessarily presupposed Community-wide action. ${ }^{19}$

Yet such an approach is to say the least open to serious criticism. To interpret the principle of subsidiarity as laying down a test for the exercise of Community competence which all proposed Community legislation is bound to pass would deprive the principle of useful effect. The rationale of the two-fold test is to determine whether the scale or effects of the proposed action would be such as to justify the adoption of Community wide rules, or whether the subject matter of the proposed action should be left to policy choices on the part of national or sub-national authorities of Member States. Community legislation by its very nature produces a Community-wide legal outcome. The core task of subsidiarity is to distinguish proposed Community measures whose objectives will (by definition) produce a Community wide outcome, from proposed measures which must produce a Community wide outcome if their objectives are to be achieved. The objectives of proposed Community action, referred to in the definition of subsidiarity, which cannot be sufficiently achieved by the Member States, but which can be better achieved at Community level, are objectives which can only be achieved by Community wide action. It might be said that the text of Article 5 implies that some objectives can be both achieved by Member States and by the Community, but not sufficiently achieved by the Member States, and better achieved by the Community. Indeed - and those objectives which can be said with confidence to be better achievable by the Community than the Member States, even if to some extent achievable by the Member States, are those

iarity: "The draft directives would lay down a set of principles on equal treatment covering key issues, including protection against harassment, the possibility for positive action, appropriate remedies and enforcement measures. These principles would be applied in all Member States, thus providing certainty for individuals about the common level of protection from discrimination they can expect. Common standards at Community level can only be achieved through co-ordinated action." For criticism of the "circularity" of the subsidiarity reasoning in the explanatory memorandum to the Proposal for a Council Directive to improve access to justice in cross-border disputes by establishing minimum common rules to legal aid and other financial aspects of civil proceedings, COM (2002) 13 final, and generally, see Eleanor Spaventa, 'The Principle of Subsidiarity and the New Proposed Protocol' (Portuguese translation) in AAVV, Uma Constituição para a Europa (Almedina Coimbra 2004)

${ }^{19}$ Case C-84/94 United Kingdom of Great Britain and Northern Ireland v Council of the European Union [1996] ECR I-5755 paras 47 and 55. 
objectives which can only be achieved at Community level. On this view, the two-fold test for compliance with subsidiarity is in truth a single test - can the objectives of the proposed action only be achieved by Community wide action.

\section{Subsidiarity guidelines support the view that the Community should only act where the objectives of the proposed action can only be achieved at Community level}

This interpretation of the test for subsidiarity is supported by the guidelines which were adopted for its implementation by the Community institutions, first in the "soft law" form adopted at the Edinburgh summit of 11-12 December 1992, and subsequently in the 1997 Amsterdam Protocol on Subsidiarity and Proportionality.

Two of these guideline are in particularly worthy of remark. The first is that the issue under consideration has transnational aspects which cannot be satisfactorily regulated by action by Member States. The second is that actions by Member States alone or lack of Community action would conflict with the requirements of the Treaty (such as the need to correct distortion of competition or avoid disguised restrictions on trade or strengthen economic and social cohesion) or would otherwise significantly damage Member States' interests. The references to transnational aspects, to distortion of competition, and disguised restrictions on trade, support an interpretation of subsidiarity which requires that Community action in areas of non exclusive competence be confined to the achievement of objectives which can be achieved only by Community wide action.

Reference to the requirements of the Treaty as including economic and social cohesion, and the indication that Community action would comply with the principle of subsidiarity where its lack "would otherwise significantly damage Member States' interests", seem to support a broader approach to subsidiarity, and indeed to establish a subjective and open ended opportunity for any proposed measure to be treated as compliant with that principle. Yet such a literal construction would seem to be inappropriate. The words referred to should be construed in light of the aim of the Protocol, and the aim of the guidelines in which the words are to be found, which is to secure implementation of the subsidiarity principle. The words referred to should thus be interpreted as meaning that any requirements of the Treaty as regards economic and social cohesion, and any significant damage to Member States' interests, be requirements and/or damage which could only remedied by Community wide action. The substantive content of subsidiarity might thus be simply summarised: in areas of non-exclusive competence, the Community should act if and only if the objectives of the proposed action can only be 
achieved by Community wide action: in such circumstances the objectives in question cannot be sufficiently achieved by the Member States, and can be better achieved by the Community.

\section{More than one rational assessment of whether proposed action complies with the principle of subsidiarity may be possible \\ Objectives for proposed action may be "mixed"- some may satisfy the subsidiarity test, others may not}

Application of this principle, as formulated above, on the other hand, is not necessarily straightforward, in that it is possible for rational individuals to come to different conclusions as regards the same proposed action. One reason for this is that the objectives of proposed action may be mixed; some objectives may not require Community wide action, other objectives may require such action. Take for example a proposed internal market measure which would harmonise certain national rules which have the aim of protection of public health. Suppose (a) that the principal aim of the measure is public health, (b) that the measure makes a very modest contribution to the internal market, and that contribution is clearly a secondary aim, but the latter contribution is sufficient for competence to be established pursuant to Article 95 EC..$^{20}$ In such a case it would, in principle, be rational (in the sense of within the range of options open to a rational decision-maker taking into account all relevant legal and factual considerations) for the Community institutions to reason (i) that the principal objectives of the proposed action (public health objectives) could not be better achieved at Community level, (ii) that these objectives could be sufficiently achieved at national level, ${ }^{21}$ (iii) that the (secondary) internal market objectives of the measure could be better achieved at Community level (this will invariably be the case ${ }^{22}$ ), (iv) that the benefits of the Community wide action would be very modest, since any positive effects on trade and market conditions resulting would be slight, and (v) that their overall assessment was thus that the measure

${ }^{20}$ It follows from case C-376/98 Federal Republic of Germany $v$ European Parliament and Council of the European Union [2000] ECR I-8419 ('Tobacco Advertising case'), that where a directive adopted under Article 95 EC pursues trade and health aims, it is necessary only that the directive makes a genuine contribution to the internal market, and not that the primary objective of the measure is to make such a contribution - see paras 76, 84 and 88; also see case C-491/01 The Queen v Secretary of State for Health, ex parte British American Tobacco (Investments) Ltd and Imperial Tobacco Ltd. [2002] ECR I-11453 paras 61 and 62.

${ }^{21}$ It is to be noted that public health remains an area of primarily national competence, and that the Title on Public Health excludes Community harmonisation, see EC Treaty art 152(4)(c).

${ }^{22}$ Case C-376/98 Federal Republic of Germany $v$ European Parliament and Council of the European Union [2000] ECR I-8419; Case C-377/98 Kingdom of the Netherlands v. European Parliament and Council [2001] ECR I-7079. 
did not comply with the principle of subsidiarity. A contrary conclusion in identical circumstances might (just) be equally rational. Different assessment might be possible of the respective weights to be attached to the various objectives of the proposed act. Even a modest contribution to the internal market might be seen as significant, and the internal market objectives of the measure might thus be seen as equal to or more significant than the public health objectives, despite the fact that that public health objectives were in themselves and in principle matters for national competence rather than Community competence, and only matters appropriate for regulation under Article $95 \mathrm{EC}$ by virtue of the overall contribution of any relevant measure to the internal market.

\section{Procedural requirements designed to facilitate analysis}

It was to facilitate analysis of such issues in a transparent and systematic way that procedural requirements were introduced - first in the Edinburgh Conclusions and in the 1993 Inter-Institutional agreement, and later in the Amsterdam Protocol - which would apply to subsidiarity appraisal during the legislative process. The procedural requirements laid down by the Amsterdam Protocol ${ }^{23}$ were (i) each institution must ensure that subsidiarity is complied with; (ii) for any proposed legislation, the reasons on which it is based shall be stated with a view to justifying its compliance with the principle of subsidiarity; (iii) the reasons for concluding that a Community objective can be better achieved by the Community must be substantiated by qualitative or wherever possible, quantitative indicators; (iv) compliance with subsidiarity should only established where action at Community level would produce clear benefits compared with action at the level of the Member States; (v) the Commission should justify the relevance of its proposals with regard to the principle of subidiarity, and wherever necessary, the explanatory memorandum accompanying a proposal shall give details in this respect; (vi) the European Parliament shall consider the consistency of Commission proposals with the principle of subsidiarity; (vii) in the course of the co-decision and co-operation procedures, the European Parliament shall be informed of the Council's position on the application of the principle of subsidiarity, by way of a statement of the reasons which led the Council to adopt its common position.

\section{Reasons must be substantiated by qualitative or wherever possible, quantitative indicators}

Two of the procedural requirements listed above are worthy of further remark. The first is the requirement that reasons for concluding that

${ }^{23}$ These requirements are similar to those set out in the Edinburgh Conclusions and the 1993 Inter-Institutional agreement. 
a Community objective can be better achieved by the Community must be substantiated by qualitative or wherever possible, quantitative indicators. Quantitative indicators (such as trade statistics and results of market research) can be of particular assistance when assessing whether any possible transnational aspects of a proposed act can or cannot be satisfactorily regulated at the national or sub national level, or when assessing possible distortions of competition or disguised restrictions on trade which will allegedly be remedied by the proposed action. Furthermore, subject matter such as transnational effects, distortions of competition, and disguised restrictions on trade, are particularly susceptible to quantitative analysis, even though this seems rarely to have been undertaken in any detail during the legislative process.

\section{Action at the Community level must produce clear benefits compared with action at the level of the Member States}

The second procedural requirement worthy of remark is that action at the Community level would produce clear benefits compared with action at the level of the Member States. This requirement is described as procedural since the reference to clear benefits stipulated a standard akin to a standard of proof. If the question of benefits at the Community level was in doubt that doubt was to be resolved in favour of the exercise of national or sub national policy choices. This "standard of proof" may be derived from the basis of the principle of subsidiarity, which is that decisions be taken "as closely as possible to the citizen." ${ }^{24}$ Since the European level is (within the Community/Union legal order) as distant as it is possible to get from the citizen, this principle might well be said to create a mild presumption against action at the European level, and it is consistent with this presumption that it be demonstrated that Community action would produce clear benefits compared with action at the level of the Member States. This in turn supports the approach indicated above, to the effect that the principle of subsidiarity should be interpreted as requiring that the Community should only act where the objectives of the proposed action can only be achieved at Community level.

\section{Enforcement of Subsidiarity by the Court of Justice}

\section{Substantive review subject to wide margin of appreciation and successful challenge on this ground close to impossible to envisage}

The Amsterdam Protocol states that "compliance with the principle of subsidiarity shall be reviewed in accordance with the rules laid down

${ }^{24}$ Treaty on European Union (Maastricht Treaty) art 1; Constitutional Protocol on the application of the principles of Subsdiarity and Proportionality (Draft Treaty establishing a Constitution for Europe, Part IV). 
by the Treaty." ${ }^{25}$ If legislation is adopted by the institutions contrary to the principle of subsidiarity this is a matter which in principle can be raised before the Court of Justice. It has always been difficult to imagine the Court annulling a Community act on the ground that the institutions had been wrong to conclude that the objectives of the proposed action could be better achieved by action at the Community level than at the level of the Member States, as a result of the wide discretion, or margin of appreciation, accorded to the institutions in the making of complex assessments. ${ }^{26}$ Nevertheless, even in the case of acts involving a complex assessment, the Court is entitled to examine the accuracy of the findings of fact and law made by the authority concerned, ${ }^{27}$ and as noted above, in the context of subsidiarity, the Court has been prepared to address the question whether "the objective of the proposed action could be better achieved at Community level". ${ }^{28}$ Yet in a case where the objectives of the act in question related both the internal market and to public health, and the latter objective was almost certainly the dominant objective, the Court considered only whether the internal market objective of moving future emerging obstacles to trade could be better achieved at Community level. ${ }^{29}$ This is in contrast to the assessment of proportionality of the act in question, which took account of public health objectives as well as internal market objectives. ${ }^{30}$ The Court's differential treatment of subsidiarity and proportionality seems designed to minimize any possibility of substantive review and create an irrebutable presumption that the objectives of internal market measures can be better achieved at Community level rather than national level.

\footnotetext{
${ }^{25}$ See $\mathrm{n} 13$.

${ }^{26}$ D Wyatt,' Subsidiarity and Judicial Review', in O'Keeffe and Bavasso (eds), Liber Amicorum in Honour of Lord Slynn of Hadley Kluwer (Subsidiarity and Judicial Review 2000) 505.

${ }^{27}$ Case C-120/97 Upjohn Ltdv. The Licensing Authority established by the Medicines Act 1968 and Others [1999] ECR I-223 para 34, citing joined cases 56 and 58-64 Établissements Consten S.à.R.L. and Grundig-Verkaufs-GmbH v Commission of the European Economic Community [1966] ECR 299, case 55/75 Balkan-Import Export v Hauptzollamt Berlin-Packhof [1976] ECR 19 para 8, case 9/82 Lene Øhrgaard and Jean-Louis Delvaux $v$ Commission of the European Communities [1983] ECR 2379 para 14, case C-225/91 Matra SA $v$ Commission of the European Communities [1993] ECR I-3203 paras 24-25, and case C-157/96 The Queen v Ministry of Agriculture, Fisheries and Food, Commissioners of Customs \& Excise, ex parte National Farmers' Union, David Burnett and Sons Ltd, R. S. and E. Wright Ltd, Anglo Beef Processors Ltd, United Kingdom Genetics, Wyjac Calves Ltd, International Traders Ferry Ltd, MFP International Ltd, Interstate Truck Rental Ltd and Vian Exports Ltd. [1998] ECR I-2211 para 39.

${ }^{28}$ Case C-491/01 The Queen v Secretary of State for Health, ex parte British American Tobacco (Investments) Ltd and Imperial Tobacco Ltd. [2002] ECR I-11453 para 180.

29 Ibid paras 61 and 181.

${ }^{30}$ Ibid paras 122-141. This cannot be explained by the way the case was argued since the applicants contended that there was no evidence for the proposition that the Member States were precluded from taking such steps to protect public health as they might wish to take, thus denying that the public health objectives of the act could be better achieved at the Community level.
} 


\section{Judicial enforcement of essential procedural requirements less problematic}

Annulment of a binding act for failure to comply with an essential procedural requirement relating to application of the principle of subsidiarity has always been a much more likely possibility than annulment for manifest error of assessment. It is unfortunately the case however that the Court's approach to the requirement that the statement of reasons of an act indicate compliance with subsidiarity has been undemanding. If the reasoning of a Community act indicates in substance the grounds for the conclusion that objectives of the act in question could not be sufficiently achieved by the Member States, this is regarded as sufficient to satisfy the procedural requirements of Community law, and there is no requirement that specific reference be made to "subsidiarity". ${ }^{31}$ The Court could and in the opinion of the present writer should, at the outset, have required more detail in the statement of reasons of an act relating to compliance with subsidiarity, in particular as regards relevant transnational aspects, as regards the existence or not of qualitative and quantitative indicators, and as regards reasons why (if this was the case) it had not been possible to substantiate compliance by reference to quantitative indicators. The texts of explanatory memoranda accompanying proposals for legislation invariably contain brief and self-serving references to subsidiarity, as do references to subsidiarity in the preambles of legislation; these practices can only have been encouraged by the Court's undemanding approach to the requirement that the statement of reasons for binding cover subsidiarity. Furthermore, it is established that the failure to take account of matters which it is essential to take into account will amount to a ground for annulment. ${ }^{32}$ Thus the failure to address transnational aspects etc., during the legislative process, would amount to infringement of an essential procedural requirement. In the case on the Working Time Directive, the United Kingdom argued that the institutions had neither fully considered nor demonstrated that there were transnational aspects etc., but the Court did not appear to consider the contention as relevant. ${ }^{33}$

\footnotetext{
${ }^{31}$ Case C-233/94 Federal Republic of Germany v European Parliament and Council of the European Union [1997] ECR I-2405 paras 22-27. There is equally no need to make a specific reference to "proportionality", see case C-150/94 United Kingdom of Great Britain and Northern Ireland v Council of the European Union [1998] ECR I-7325 para 37.

32 Case 191/82 EEC Seed Crushers' and Oil Processors' Federation (FEDIOL) v Commission of the European Communities [1983] ECR 2913 para 30; scrutiny to determine whether institution has omitted to take into consideration any essential matters part of normal powers of review of the Court of Justice.

${ }^{33}$ Case C-84/94 United Kingdom of Great Britain and Northern Ireland v Council of the European Union [1996] ECR I-5755 para 46. A similar argument was made in case C-491/01 The Queen v Secretary of State for Health, ex parte British American Tobacco (Investments) Ltd and Imperial Tobacco Ltd. [2002] ECR I-1 1453, but the point was not referred to by the Court.
} 


\section{The position under the Constitution Treaty}

\section{Duty of the institutions to ensure respect for subsidiarity - stronger duty to demonstrate compliance, but abbreviated guidelines}

The Constitution Protocol on Subsidiarity and Proportionality confirms the duty of the institutions (i) to ensure respect for the principle of subsidiarity, as laid down in Article 1-11 of the Constitution, ${ }^{34}$ and (ii) to justify acts as regards compliance with subsidiarity. ${ }^{35}$ The Protocol somewhat strengthens the obligation to provide justification of draft legislative acts with regard to subsidiarity. In the Amsterdam Protocol, the obligation was to give details in this respect "wherever necessary"; in the Constitution Protocol any draft European legislative act "should contain a detailed statement making it possible to appraise compliance with... subsidiarity." The Amsterdam guidelines (transnational aspects etc) are abbreviated to the short statement that "the reasons for concluding that a Union objective can be better achieved at Union level shall be substantiated by qualitative and, wherever possible, quantitative indicators." It is not considered that this would have the effect of reducing the grounds on which draft legislative acts could be scrutinized for conformity with subsidiarity by confining scrutiny to the abovementioned considerations. Subsidiarity is a fundamental principle with clearly expressed aims and a basis in primary law. The Community institutions would be bound to apply that principle in accordance with its text and its aims and taking account of all relevant factual and legal considerations, including, for example, whether the proposed action would have transnational effects, or would correct distortions of competition.

\section{Monitoring by national parliaments - the "yellow card"}

The preamble of the Constitution Protocol on Subsidiarity and Proportionality records that the High Contracting Parties are resolved to establish a system for monitoring the application of those principles. As noted above, this monitoring is to be carried out by national parliaments and by the European Court of Justice. National parliaments are under a duty to ensure compliance with the principle of subsidiarity pursuant to Article I-11(3). Where reasoned opinions on a draft legislative act's non-compliance with the principle of subsidiarity represent at least one third, or one quarter as the case may be, ${ }^{36}$ of all the votes allocated to the national parliaments, the draft must be reviewed, and the competent

\footnotetext{
${ }^{34}$ Protocol (n 24) art 1.

35 Protocol (n 24) art 5.

${ }^{36}$ In the case of a draft legislative act submitted on the basis of art III-264 on the area of freedom, security and justice.
} 
institution may decide to maintain, amend or withdraw the draft. Reaching these thresholds for review have been described as analogous to the raising of a yellow card by the referee in a football match. Reasons must be given for a decision to maintain, amend or withdraw a draft. These arrangements provide for monitoring of the application of the principle of subsidiarity by political institutions in the course of the lawmaking process. Yet the requirement for reasoned opinions on the part of the national parliaments, and for reasons to be given if the competent institution at the Union level decides to maintain, amend or withdraw the draft legislative act in question, would be likely at least to some extent to formalise and perhaps systematise, subsidiarity scrutiny at both the Union level, and the level of national parliaments. Even if the competent institution (for example the Commission) decided to maintain a draft to which objection had been made by the requisite number of national parliaments, it would be open to other institutions (for example the Council and European Parliament) to take into account and, if they considered it appropriate, act upon, the reasoned opinions of the national parliaments. The House of Lords EU Committee Report referred to above expressed the view that "the raising of a yellow card would have a significant effect on the EU institutions...if national parliaments operate the mechanism effectively it would be hard for the Commission and the Council to resist such sustained political pressure." 37

\section{Would and should a "yellow card" alter the dynamics of judicial enforcement of subsidiarity?}

\section{Light touch review or a new approach by the Community Courts}

Article 8 of the Protocol provides that the Court of Justice shall have jurisdiction in actions on grounds of infringement of the principle of subsidiarity by a European legislative act. It might of course be the case that the light touch review applied by the Court of Justice in cases where infringement of the principle of subsidiarity is alleged would be maintained even if the monitoring mechanisms of the Protocol come into force. Yet that is not certain. As the House of Lords EU Committee Report states: "The Protocol reaffirms that application of the principle of subsidiarity must be properly substantiated in each case. National parliaments can be expected to look closely at this and can reasonably expect the Court to do likewise." 38

It is certainly feasible that the competences and responsibilities allotted to national parliaments and the lawmaking institutions under the

${ }_{37}$ Report (n 10) para 126.

${ }^{38}$ Report (n 10) para 243. 
Protocol might be held to affect the course of any subsequent legal proceedings (were the Constitution Treaty to come into force or were such monitoring by national parliaments to be otherwise introduced) in which the compliance of a legislative act with the principle of subsidiarity were raised.

\section{Absence of a yellow card might preclude review other than on grounds of lack of reasoning}

In the first place, a plea before the Court of Justice that the principle of subsidiarity had been infringed by a European legislative act, ${ }^{39}$ where national parliaments had not "raised a yellow card," might be regarded by the Court of Justice as prima facie unfounded - even manifestly unfounded, except perhaps as regards a plea that the legislative act as adopted should be annulled for want of reasoning, though even in such a case the implicit endorsement of national parliaments might be considered to deprive a procedural challenge of useful purpose.

\section{Where the Commission resists a yellow card, the issue in subsequent legal proceedings ought to be whether the yellow card was manifestly unfounded}

Where, by way of contrast, national parliaments had "raised a yellow card" to a Commission draft, but the Commission had maintained its draft, with reasons, and the draft had been subsequently adopted, one possibility (which the present writer would advocate) would be that the Court of Justice would regard it as a procedural requirement essential to the validity of the act in question that the reasons of the Commission demonstrate that the national parliaments had made a manifest error of appraisal in objecting to the draft act on subsidiarity grounds. That is to say, the focus of the legal challenge would be on the question whether the national parliaments had acted rationally, in the sense of having properly directed themselves in fact and law, and having taken into account all relevant considerations, in objecting to the proposed act on subsidiarity grounds. To review compliance of a legislative act with the principle of subsidiarity via scrutiny of the defensibility of the objections raised by national parliaments would be preferable to purporting to review in its entirety the conduct of the lawmaking institutions in the lawmaking process. It would certainly be more practical. Experience has shown that the Court of Justice has been unwilling to consider seriously arguments to the effect that Council and Parliament have failed to take account, or adequately to take account of the subsidiarity guidelines in

39 That is to say, a draft European law or European framework law; see art I-33. 
the Amsterdam Protocol. But establishing the strict accuracy of such claims, and counterclaims by the institutions could never be easy, given the lack of transparency of the proceedings of the Council (though this may soon change ${ }^{40}$, and relative complexity of proceedings in the Parliament. Review of the kind proposed above would ensure that appropriate weight would be accorded to the assessment of the national parliaments, in recognition of their special responsibility for monitoring subsidiarity. It would also focus scrutiny on the steps in the lawmaking process in which compliance with the principle of subsidiarity could be and should be most transparent - the legislative proposal, the justification of that proposal in subsidiarity terms by the Commission, the objections by national parliaments to that proposal on subsidiarity grounds, and the response by the Commission to those objections. Whether the Commission maintained or amended a draft legislative act in response to a "yellow card", the above suggested procedure would provide a workable and almost certainly effective mechanism for judicial scrutiny of compliance with the principle of subsidiarity. It would strike a new and appropriate balance between political assessment and judicial control.

\section{Such a synthesis of political and judicial control would require a new approach by the Court of Justice}

That is not to say that the Court of Justice would actually adopt such an approach. But it could. And the present writer would submit that it should. European integration does not depend upon an insistent stream of European legislation. Europe should legislate only where there is a clear case for action and Europe and Europe alone can undertake such action effectively. That is the real underlying logic and legitimacy of subsidiarity. Europe should act where the option of acting alone is not a truly viable option. Such an approach does not undermine the European project, it makes it immeasurably stronger. One reason why such efforts have to be made to "sell" Europe to its citizens is that so many of its citizens simply cannot see why responsibility for so much legislation is taken at European level, rather than at national or regional level.

For more than forty years the European Court has devised and refined legal principles designed to attribute authority to the European institutions and supremacy to the acts of those institutions. Without that judicial effort the European Union would lack effectiveness and credibility. But the Court's single greatest weakness to date has been its refusal to accept the legitimacy of one of the central constitutional principles of

${ }^{40}$ According to a press release of 30 June 2006, one aim of the Finnish Presidency of JulyDecember 2006 will be that "greater transparency will be achieved above all through open sessions of the Council, which citizens will be able to follow via the Internet...." 
the Union legal order. The Member States have by incorporating it into primary law made subsidiarity part of the normative constitution of the Union; yet the Court of Justice gives every appearance of refusing to accept it as part of the ideological constitution of which the Court sees itself as guardian. But times change. And what the European Union needs at the present time is to balance centralizing values with the decentralizing value of subsidiarity. The present writer would not rule out the possibility that the collective commitment to subsidiarity signaled by the introduction of monitoring by the national parliaments would present the Court with a new situation in constitutional terms which would trigger an appropriate judicial response.

\section{Monitoring by national parliaments is achievable even if the Constitution Treaty in its present form does not go forward}

Although it appears unlikely that the Constitution Treaty will come into force, at least in its present form, and under its present name, that fact need not necessarily prevent the introduction of subsidiarity monitoring by national parliaments. Such monitoring might come into effect as a result of a package Treaty changes which fall short of the adoption of a Constitution Treaty. Even without Treaty changes, voluntary cooperation between the national parliaments and the Community institutions, perhaps formalized by joint declarations establishing the agreed framework, would be sufficient to put in place machinery close in content and effects to that contemplated by the Constitution Treaty Protocol on Subsidiarity and Proportionality. The House of Lords EU Committee Report expressed the view that "even if the Constitutional Treaty does not enter into force, the provisions relating to national parliaments and to subsidiarity can and should provide a stimulus to greater and more effective scrutiny by all national parliaments in the EU." ${ }^{41}$ It is to be hoped that this assessment proves correct. Giving teeth to subsidiarity by entrusting national parliaments with responsibility for monitoring its application, and reinforcing that responsibility with an appropriate judicial response from the Court of Justice, could increase the accountability and legitimacy of European lawmaking bodies, and could enhance in an unprecedented way the sense of "ownership" of the European project at national level.

${ }^{41}$ Report (n 10) para 281. 
